\title{
ANTIBODIES AGAINST MOUSE OVARIES AND THEIR EFFECT ON FERTILIZATION IN VITRO AND IN VIVO IN THE MOUSE
}

\author{
F. JÍLEK AND A. PAVLOK \\ Czechoslovak Academy of Sciences, Institute of Animal Physiology and Genetics, \\ Department of Genetics, Liběchov, Czechoslovakia
}

(Received 12th July 1974)

Recent studies on the antigenicity and immunogenicity of mammalian ovaries and eggs have shown that iso- or heteroimmunization with ovarian tissue will yield antibodies with which several ovarian antigens can be detected. Immunofluorescence techniques have shown that these antigens are localized in the zona pellucida, the theca interna and in atretic follicles (Porter, 1965; Porter, Highfill \& Winovich, 1970a, b; Ownby \& Shivers, 1972; Sacco \& Shivers, $1973 \mathrm{a}, \mathrm{b}, \mathrm{c}, \mathrm{d}$ ). Antisera (by precipitate formation) modified the surface of the zona pellucida of hamster and rabbit ova to such an extent that it even became inert to the lytic effects of trypsin (Ownby \& Shivers, 1972; Sacco \& Shivers, 1973a). In hamsters, these antibodies blocked penetration of the zona pellucida by spermatozoa in vitro (Shivers, Dudkiewicz, Franklin \& Fussell, 1972). Shahani, Padbidri \& Rao (1969, 1972) demonstrated inhibition of conception in vivo in mice by antisera against mouse ovaries, but did not explain the mechanism of their effect in detail. The aim of the present study was to investigate the specificity and mechanism of the effect of heteroimmune antibodies against mouse ovaries in fertilization in vitro and in vivo.

Mouse ovarian extract for immunization of rabbits was prepared by homogenization of washed ovaries with phosphate-buffered saline $(\mathrm{pH} 7 \cdot 2)$ at $4^{\circ} \mathrm{C}$ in the ratio of 1 part ovaries to 3 parts buffer $(w / w)$. The homogenate was centrifuged for $15 \mathrm{~min}$ at $670 \mathrm{~g}$ and the supernatant was used for immunization. The sediments of the tissue homogenates were used for absorption.

Intramuscular injection of $0.5 \mathrm{ml}$ supernatant with $0.5 \mathrm{ml}$ complete Freund's adjuvant was given every week. Blood was collected from the marginal ear vein on the 10th day after the sixth injection. The resultant serum was inactivated for $30 \mathrm{~min}$ at $56^{\circ} \mathrm{C}$ and was absorbed by normal mouse serum in a $1: 1$ ratio and by the sediment of mouse liver, spleen and kidney tissue homogenate, in the same ratio. This was termed specific immune serum (SIS). This serum absorbed twice by mouse ovarian tissue (ovary-absorbed immune serum-OAIS) served as the control.

Since the reaction of the antisera in Ouchterlony's test (Ouchterlony, 1949) and immunoelectrophoresis was relatively weak, they were tested by indirect immunofluorescence only, using pig anti-rabbit IgG labelled with fluorescein isothiocyanate (SwAR/FITG) supplied by SEVAC (Prague). 
Tests on tissue sections were performed by Sainte-Marie's method (SainteMarie, 1962).

Reactions of antibody with live eggs were also studied. The eggs were incubated for $45 \mathrm{~min}$ at $37^{\circ} \mathrm{C}$ in SIS diluted $1: 1$ with culture medium. They were washed twice in a watch-glass, SwAR/FITC was applied and they were again washed twice and mounted with buffered glycerol $(\mathrm{pH} \mathrm{8.0)}$ under a coverslip. In the controls, SIS was replaced by normal rabbit serum (NS) and OAIS.

The preparations were evaluated in a Fluoval microscope (Carl Zeiss, Jena) using an HBO-200 W lamp, with BG 12 + GG 13 excitation filters and an OG 4 barrier filter.

The anti-fertilizing effect of SIS was tested in $\mathrm{C} 57 \mathrm{BL} 10 \mathrm{ScSn} / \mathrm{Ph} \times \mathrm{A} / \mathrm{Ph}$ hybrid mice aged 10 to 16 weeks. Fertilization in vitro, including superovulation, lysis of the zona pellucida and the evaluation method has been described in a previous paper (Pavlok \& McLaren, 1972), but in the present experiments, the volume of culture medium per dish was increased from $30 \mu \mathrm{l}$ to $100 \mu \mathrm{l}$ and the eggs were incubated in the medium for at least $40 \mathrm{~min}$ before adding the spermatozoa. The SIS, OAIS or NS was added to the medium in 1.25 to $10 \%$ concentrations just before adding the eggs. The sera were preabsorbed by mouse epididymal spermatozoa to remove natural spermagglutinins. Plain basic medium, medium with added NS or medium with OAIS (when testing the active SIS concentration) acted as the control. In a second experiment, SIS and NS $(0.3 \mathrm{ml} /$ animal) were injected subcutaneously into sixteen mice about $7 \mathrm{hr}$ after PMSG and into four mice $31 \mathrm{hr}$ after PMSG. At $46 \mathrm{hr}$ after PMSG, HCG was injected and the animals were mated 4 to $6 \mathrm{hr}$ later. The methods for superovulation and evaluation of fertilization (24 to $27 \mathrm{hr}$ after HCG) were as for fertilization in vitro.

When using the immunofluorescence method to determine the binding of antibody administered in vivo, SwAR/FITC was applied immediately to flushed eggs.

Immune non-absorbed serum gave positive results, as detected by the indirect immunofluorescence method, with all tested tissues (spleen, kidney, liver, lung, uterus, heart, ovary). The SIS gave reactions in the zona pellucida only, both in ovarian sections and in live oocytes (Pl. 1, Fig. 1), while OAIS gave

\section{EXPLANATION OF PLATE 1}

Fig. 1. Mouse eggs tested by indirect immunofluorescence following treatment with specific immune serum (SIS) and pig anti-rabbit IgG labelled with fluorescein isothiocyanate (SwAR/FITC). There is a distinct reaction on the zona pellucida. $\times 350$.

FIG. 2. Mouse eggs tested by indirect immunofluorescence following treatment with ovary-absorbed immune serum and SwAR/FITC. There is no reaction on the zona pellucida. $\times 350$.

Fig. 3. A penetrated mouse egg fertilized in vitro in control medium. Before fixation, phase contrast. $\times 350$.

FIG. 4. An intact non-penetrated mouse egg which was unfertilized in vitro in medium containing $5 \%$ SIS. Before fixation, phase contrast. $\times 350$.

FIG. 5. Penetrated mouse eggs fertilized in vitro without the zona pellucida, in medium containing $5 \%$ SIS. Before fixation, phase contrast. $\times 350$.

FIG. 6. Unfertilized egg at metaphase II of meiotic division (arrow) isolated from a mouse treated with $0.3 \mathrm{ml}$ SIS $25 \mathrm{hr}$ after HCG and $20 \mathrm{hr}$ after mating. Fixation with acetic alcohol, staining with acetic orcein. Phase contrast. $\times 300$. 

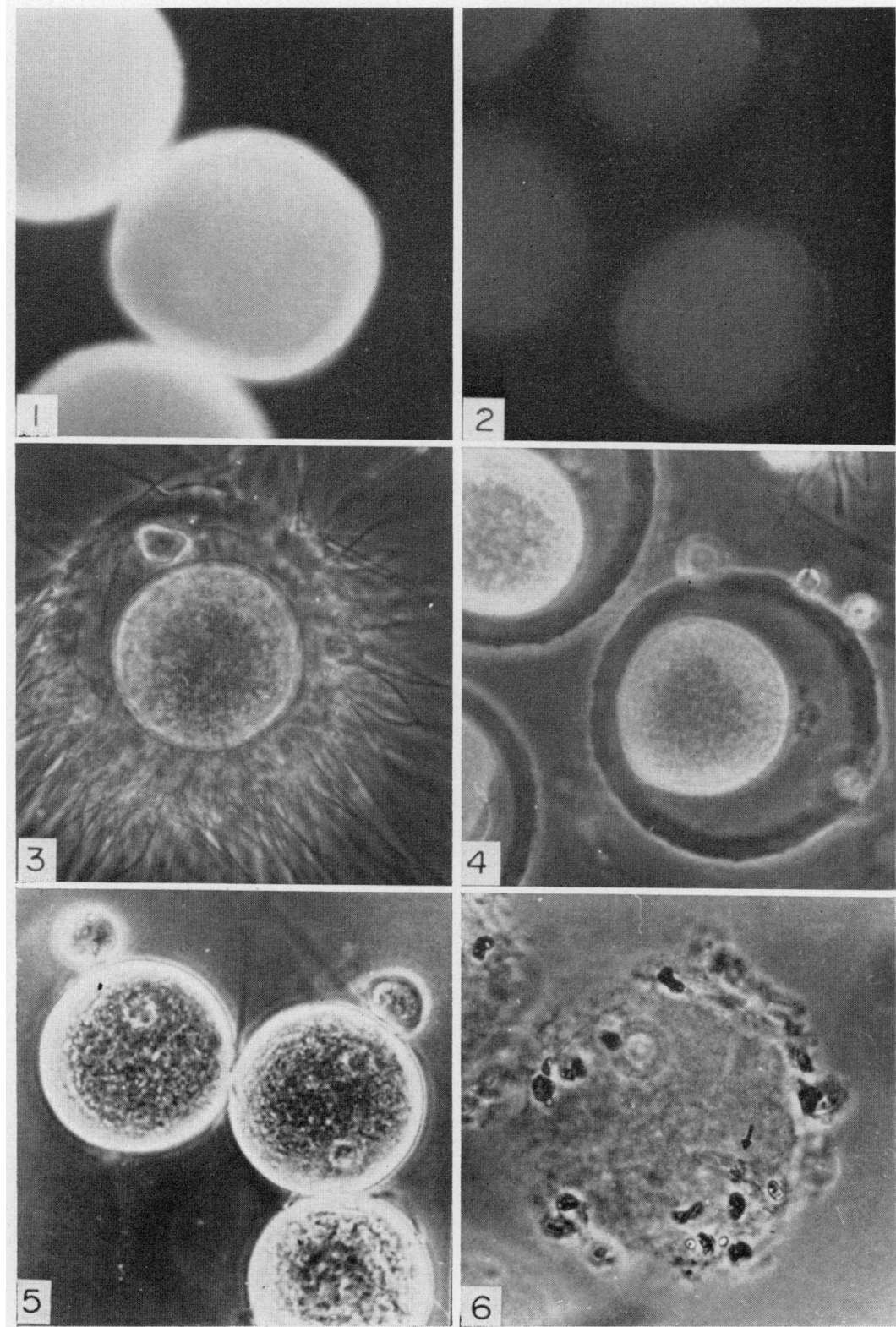

(Foing f. 378 
no reactions (P1. 1, Fig. 2). After administration in vivo, the presence of antibodies on the oocytes was detected by indirect immunofluorescence, both in ovulated eggs and in eggs aspirated from the follicles shortly before ovulation.

The effect of antiovarian rabbit heteroimmune antiserum on fertilization in mice is shown in Table 1. The antiserum had no effect on the dispersion of

Table 1. Effect of antiovarian rabbit heteroimmune serum on fertilization in mice

\begin{tabular}{|c|c|c|c|c|c|c|}
\hline \multirow{3}{*}{ Treatment } & \multicolumn{4}{|c|}{ In vitro } & \multirow{2}{*}{\multicolumn{2}{|c|}{$\begin{array}{c}\text { In vivo } \\
\text { Time } \\
\text { after } P M S G(h r)\end{array}$}} \\
\hline & \multirow{2}{*}{$\begin{array}{l}\text { Concen- } \\
\text { tration of } \\
\text { sera }(\%)\end{array}$} & \multirow{2}{*}{$\begin{array}{c}\text { Intact } \\
\text { ova } \\
\text { (Exp. 1) }\end{array}$} & \multirow{2}{*}{$\begin{array}{l}\text { Zona- } \\
\text { free } \\
\text { ova }\end{array}$} & \multirow{2}{*}{$\begin{array}{c}\text { Intact } \\
\text { ova } \\
\text { (Exp. 2) }\end{array}$} & & \\
\hline & & & & & 7 & 31 \\
\hline $\begin{array}{l}\text { Specific } \\
\text { immune } \\
\text { serum }\end{array}$ & $\begin{array}{l}10 \\
5 \\
2 \cdot 5 \\
1 \cdot 25\end{array}$ & $\begin{array}{l}0(21) \\
0(57) \\
-\end{array}$ & $\begin{array}{c}100(21) \\
100(53) \\
-\end{array}$ & $\begin{array}{r}0(73) \\
1.7(60) \\
7 \cdot 2(69)\end{array}$ & $0.6(158)$ & $0(48)$ \\
\hline $\begin{array}{l}\text { Ovary- } \\
\text { absorbed } \\
\text { immune } \\
\text { serum }\end{array}$ & $\begin{array}{l}5 \\
2 \cdot 5 \\
1 \cdot 25\end{array}$ & $\bar{z}$ & E & $\begin{array}{r}57 \cdot 9(57) \\
60(75) \\
77 \cdot 8(63)\end{array}$ & - & - \\
\hline $\begin{array}{l}\text { Control } \\
\text { serum }\end{array}$ & $\begin{array}{r}10 \\
5\end{array}$ & $\begin{array}{r}94 \cdot 4(18) \\
93(57)\end{array}$ & $\begin{array}{r}100(20) \\
96 \cdot 4(55)\end{array}$ & $=$ & $97 \cdot 1$ (139) & $91 \cdot 4(35)$ \\
\hline $\begin{array}{l}\text { Untreated } \\
\text { medium }\end{array}$ & - & $89(82)$ & $97 \cdot 3(76)$ & $70 \cdot 9(55)$ & - & - \\
\hline
\end{tabular}

The values show the percentage of eggs fertilized. The number of eggs examined is given in parentheses.

cumulus and corona radiata cells by the spermatozoa (Pl. 1, Figs 3 and 4). The antifertilization effect of the antibodies was due to prevention of adhesion of the spermatozoa to the surface of the zona pellucida and their subsequent penetration into the perivitelline space, a finding which agrees with the results of Shivers et al. (1972). The inclusion of a group of zona-free control eggs and their normal fertilization, even in a relatively high SIS concentration (P1. 1, Fig. 5), provided further evidence of the physiological specificity of these antibodies.

The administration in vitro of antiovarian antibodies confirmed the results of Shahani et al. (1972) on their contraceptive effect. The cause of contraception under conditions in vivo again seems to be a block to sperm penetration through the zona pellucida, on which antibodies were actually detected within the follicles by immunofluorescence. Flushing of the oviducts 12 to $14 \mathrm{hr}$ after ovulation revealed not only unfertilized denuded eggs at the stage of metaphase II of meiosis (Pl. 1, Fig. 6), but also isolated, partly phagocytosed, spermatozoa. Unlike Shahani et al. (1972), who achieved a $100 \%$ contraceptive effect only when antibodies were administered during dioestrus, sperm penetration in our experiments was blocked irrespective of whether antibodies were administered 39 to $15 \mathrm{hr}$ before injecting HCG. 
The inhibitory effect of antiovarian antibodies on ovulation observed by Porter (1965) was not confirmed in our experiments.

Differences in the percentage of fertilized eggs that occur with different OAIS concentrations are evidently not of immunological origin.

\section{REFERENCES}

Ouchterlony, O. (1949) Antigen-antibody reactions in gels. Acta path. microbiol. scand. 26, 507-515.

OwnBy, C. L. \& Shivers, C. A. (1972) Antigens of the hamster ovary and effects of anti-ovary serum on eggs. Biol, Reprod. 6, 310-318.

Pavlok, A. \& Mclaren, A. (1972) The rôle of cumulus cells and the zona pellucida in fertilization of mouse eggs in vitro. 7. Reprod. Fert. 29, 91-97.

Porter, C., Highfill, D. \& WinOvich, R. (1970a) Guinea pig ovary and testis: demonstration of common gonad specific antigens in the ovary and testis. Int. F. Fert. 15, 171-176.

Porter, C., Highrill, D. \& Winovich, R. (1970b) Guinea pig ovary and testis: localization of common gonad specific antigens. Int. F. Fert. 15, 177-181.

Porter, C. W. (1965) Ovarian antibodies in female guinea pigs. Int. F. Fert. 10, 257-260.

SAcco, A. G. \& SHIvErs, G. A. (1973a) Effect of reproductive tissue-specific antisera on rabbit eggs. Biol. Reprod. 8, 481-490.

SAcco, A. G. \& Shrvers, C. A. (1973b) Antigens of the rabbit ovary, oviduct and uterus. F. Reprod. Fert. 32, 403-414.

SAcco, A. G. \& Shivers, C. A. (1973c) Localization of tissue-specific antigens in the rabbit ovary, oviduct and uterus by the fluorescent antibody technique. 7. Reprod. Fert. 32, 415-420.

SAcco, A. G. \& Shivers, C. A. (1973d) Comparison of antigens in the ovary, oviduct and uterus of the rabbit and other mammalian species. F. Reprod. Fert. 32, $421-427$.

SaINTE-MARIE, G. (1962) A paraffin embedding technique for studies employing immunofluorescence. 7. Histochem. Cytochem. 10, 250-256.

Shahani, S. K., Padbidri, J. R. \& Rao, S. S. (1969) Antifertility studies with immune sera to mouse ovarian tissue. Indian F. exp. Biol. 7, 52-53.

Shahani, S. K., Padbidri, J. R. \& RAo, S. S. (1972) Immunobiological studies with the reproductive organs, adrenals and spleen of the female mouse. Int. F. Fert. 17, 161-165.

Shrvers, G. A., Dudkiewicz, A. B., Franklin, L. E. \& Fussell, E. N. (1972) Inhibition of spermegg interaction by specific antibody. Science, N.Y. 178, 1211-1213. 